\title{
Parafia rzymskokatolicka w świadomości młodzieży polskiej przełomu wieków. Badania socjologiczne z lat 1988-2018
}

\begin{abstract}
In this paper I present a widely understood attitude of gymnasium, high school and academic youth in Poland in the two last decades of the 20th century and both first decades of the 21st century towards the Roman-catholic parish as a church institition and a socio-religious community of secular Catholics. The basis for the presented issues is being made by the research outcome of various sociologists of religion undertaken in the mentioned time frame. The main issue is being made here by the general question - how did shape in this time frame the attitude of the youth towards the Roman-catholic parish? The goal of this paper is to present the declaration of the youth related to the attitude towards the home parish. The presented investigations use the method of the analysis of in situ data and a comparison of various related research.
\end{abstract}

Keywords: Roman-catholic parish, the attitute of youth towards home parish, gymnasium youth, high school students, students, consciousness

\section{Wstęp}

zy istnieje zobiektywizowana i integralna definicja parafii katolickiej? Jakiego rodzaju rzeczywistością jest dzisiejsza parafia rzymskokatolicka - czy wyłącznie religijno-kościelną, czy też religijno-społeczną - wziąwszy pod uwagę specyfikę 
obecnych uwarunkowań życia ludzi i pogłębiający się kryzys autorytetu Kościoła instytucjonalnego, w ramach którego parafia jest ciągle integralną częścią i podstawową strukturą diecezji? Jaki model parafii jest obecnie w pełni dostosowany do warunków bytowych i oczekiwań religijno-społecznych dzisiejszych ludzi: parafia postrzegana instytucjonalnie, wspólnotowo-religijnie czy teologicznie? Czy socjologowie dostrzegają problem patologii w życiu parafialnym w obu jego wymiarach - religijnym i świeckim, w stylach i formach zarządzania jej dobrami, kierowania religijnością i moralnością wiernych przez duchowieństwo? Na czym polegają trudności w urzeczywistnianiu idei parafii w religijności i w codziennym życiu ludzi na wioskach i w miastach? Jakie czynniki (przyczyny, motywy) wywołują te problemy i odsuwanie się katolików od parafii, czy też zanikanie ich styczności i więzi z parafią jako instytucją kościelną i wspólnotą wiernych? Jakie nastawienie do parafii przejawiała młodzież polska w przyjętym okresie?

Młodzież polska znajduje się w polu napięć pomiędzy sekularyzacją i ewangelizacją, więc nie można jej opisać w kategoriach jednorodnego faktu społecznego. Z jednej strony jest silny proces sekularyzacji (na przykład kryzys przekazu wiary), z drugiej strony ważne są oddziaływania Kościoła katolickiego i innych wyznań chrześcijańskich oraz nowych ruchów religijnych na świadomość młodych (ewangelizacja czy nowa ewangelizacja). W konsekwencji tych sprzecznych oddziaływań społeczno-kulturowych należy przyjąć „,wielościeżkową” interpretację procesów przemian w religijności młodzieży polskiej (między sekularyzacją i ewangelizacją). Wielu badaczy prognozuje w Polsce te same procesy przemian w religijności młodzieży co w krajach zachodnioeuropejskich (sekularyzm czy laicyzm jest dobrym towarem eksportowym), zaś inni są skłonni zarezerwować „specyficzną ścieżkę” rozwojową religijności w środowiskach młodzieżowych ${ }^{1}$. Wojciech Świątkiewicz twierdzi:

[...] jeżeli pokoleniu młodzieży przypada szczególna rola kształtowania przyszłości kultury i religijności, modelowania aspiracji, stylów życia, wzorów konsumpcji, albo też eliminujących je z postulowanego kanonu nowoczesności, to dokonana diagnoza kondycji religijnej młodzieży ma nie tylko znaczenie teoretyczne i naukowe, ale i praktyczne oraz wychowawcze ${ }^{2}$.

Problematyka tego artykułu mieści się w ramach paradygmatu zatytułowanego „ciągłość i zmiana”. Ciągłość ta oznacza i obejmuje trwałość niektórych elementów w identyfikacjach wyznaniowych, religijnych i kultycznych młodzieży polskiej z parafią macierzystą w przyjętym przedziale czasu - na przełomie XX i XXI wieku. Zmiana zaś obejmuje te elementy wspomnianych identyfikacji wyznaniowych,

${ }^{1}$ R. Boguszewski, Od zinstytucjonalizowanej do zindywidualizowanej religijności Polaków w procesie przemian, w: Globalny i lokalny wymiar religii. Polska w kontekście europejskim, red. I. Borowik, A. Górny, W. Świątkiewicz, Nomos, Kraków 2016, s. 136.

${ }^{2}$ W. Świątkiewicz, Młodzież a religia, w: Leksykon pedagogiki religii, red. C. Rogowski, Verbinum, Warszawa 2007, s. 418. 
religijnych i kultycznych polskiej młodzieży z parafią, które wystąpiły w jej życiu religijnym w tym okresie pod presją różnych czynników obiektywnych od niej niezależnych i czynników subiektywnych związanych z jej postawami, przekonaniami i zachowaniami o profilu religijnym, dotyczących parafii. Problem główny został ujęty w następującym pytaniu ogólnym: jak kształtowało się nastawienie polskiej młodzieży (gimnazjalnej, licealnej i akademickiej) do parafii rzymskokatolickiej jako instytucji i wspólnoty wiernych w swym wymiarze pozytywnym (trwałości) i negatywnym (zmiany) w przyjętym okresie 30 lat? Z tego pytania wywodzą się pytania szczegółowe, które będą ukazane dalej w analizie podjętej tu problematyki. Przedmiotem tego opracowania jest nastawienie młodzieży polskiej do parafii rzymskokatolickiej, zaś jego celem jest ukazanie deklaracji tej młodzieży dotyczących jej identyfikacji związanych z parafią w przyjętym przedziale czasu. W opracowaniu tym niezbędna okazała się metoda analizy i prezentacji wyników badań socjologicznych zrealizowanych na ten temat w latach 1988-2018. Metody porównawczej nie można było zastosować w pełni ze względu na odmienne założenia badawcze stosowane przez autorów w tym okresie.

\section{Socjologiczne ujęcie parafii rzymskokatolickiej}

\section{Elżbieta Firlit zaznacza:}

Parafia rzymskokatolicka jest nie tylko instytucją religijną i elementarną strukturą Kościoła, ale również ważną instytucją społeczną o szerokim spektrum w różnych obszarach życia lokalnych społeczności. Jako instytucja zakorzeniona lokalnie, będąca dla wielu osób istotną częścią ich ojczyzny prywatnej, jest ważnym ośrodkiem życia społecznego w wymiarze lokalnym, jest - jak to określają niektórzy socjologowie religii - „ośrodkiem skupienia społecznego”, którego znaczenie wzrasta w okresie intensywnych przemian społeczno-kulturowych. W świadomości lokalnych społeczności parafia pozostaje miejscem bliskim, przyjaznym, oswojonym, miejscem, w którym zdecydowana większość ludności czuje się emocjonalnie związana. Kościół parafialny, jako szczególna instytucja religijna i kulturowa, jest trwałym elementem kultury lokalnej, [...] kościół parafialny jest nadal nie tylko centrum religijnego życia społeczności lokalnych, ale jest również instytucją, która nieodmiennie wiele lat towarzyszy najważniejszym, przełomowym wydarzeniom w życiu jednostek i rodzin oraz całych społeczności. [...] Zmiana kontekstu społeczno-politycznego po przełomie ustrojowym z czerwca 1989 roku nie osłabiła tradycyjnych więzi mieszkańców lokalnych społeczności z parafią. [...] Księża parafialni są niewątpliwie liderami w obrębie swoich parafii, [...] odgrywają oni pierwszorzędną rolę nie tylko w zarządzaniu parafią i w sprawowaniu podstawowych religijnych funkcji, ale także w animowaniu i realizacji społecznej działalności parafii, czyli w pełnieniu jej funkcji intensywnych ${ }^{3}$.

${ }^{3}$ E. Firlit, Parafia rzymskokatolicka w Polsce w okresie transformacji systemowej. Studium socjologiczne, Elipsa, Warszawa 1998, ss. 293-295. 
Aktualna literatura socjologiczna poświęcona problematyce parafii wskazuje na dwa podstawowe nurty postrzegania istoty parafii: nurt klasyczny i nurt kryzysu jej funkcjonowania. Nurt klasyczny zakłada, że parafia stanowi elementarną strukturę Kościoła instytucjonalnego, która ułatwia mu codzienne funkcjonowanie i wykonywanie zadań wynikających z jego podstawowej misji religijnej ${ }^{4}$. Reprezentanci nurtu wskazującego na kryzys funkcjonowania parafii informują o powolnym „obumieraniu” samej idei parafii tradycyjnie pojmowanej. Parafia tradycyjna, w ich ocenie, przestaje obecnie odgrywać podstawową rolę w świadomości i życiu codziennym ludzi, przez co wielu katolików zatraca osobiste poczucie przynależności parafialnej5

Więź katolików z parafią jest przejawem lub formą ich więzi z Kościołem instytucjonalnym. Georg Schmidtchen twierdzi, że „bez stałego związku ze strukturą grupową konkretnej wspólnoty religijnej, czyli konkretnej parafii, praktycznie nie istnieje więź katolików z Kościołem instytucjonalnym”6. Zdaniem Janusza Mariańskiego: „żywotność więzi parafialnej oznacza przejaw i wskaźnik instytucjonalnych związków katolików z religią"7.

W socjologicznym opisie świadomości parafialnej katolików podstawowe znaczenie ma przyjęcie odpowiedniej typologii parafii. Stefan Nowakowski pisał, że: „stanowiąca grupę rodzinno-sąsiedzką wieś tradycyjna była związana z systemem parafialnym, w którego ramach przebiegało życie przeciętnego mieszkańca. Tylko z rzadka wykraczał on poza owe ramy, co wiązało się ze służbą w wojsku, albo ze sporadycznymi raczej kontaktami z pobliskim miastem”. Stefan Knobloch wskazuje na trzy typy parafii, odwołując się zarazem do typologii Hermanna Steinkampa $^{9}$, a mianowicie: 1) parafia jako typ hierarchiczny), 2) parafia jako organizacja, 3) parafia jako wspólnota ${ }^{10}$.

${ }^{4}$ G. Bonicelli, La parrocchia Italaiano la vent'anni dal Conzilio Vaticano II, w: Oltre l'indifferenza. La parrocchia a vent'anni dal Conzilio, Edizione Dehoniane, Napoli 1985, ss. 7-30; R. Kamiński, Parafia jako forma urzeczywistniania się Kościoła, w: Dei Virtus. Kardynałowi Bolesławowi Kominkowi w hołdzie, red. J. Krucina, Wydawnictwo Księgarni Archidiecezjalnej, Wrocław 1974, ss. 26-29; W. Piwowarski, Problemy duszpasterskie w strefie urbanizacji, „Przegląd Powszechny” 1982, nr 3, ss. 22-25.

${ }^{5}$ R. Metz, W. Goddijn, La parroise en France al. époque modern et contemporaine, „Revue d'Histoire de l'Eglise de France” 1975, nr 166, ss. 6-8; W. Goddiijn, Sichtbare Kirche. Okumene und Pastoral, Herder, Wien 1967, ss. 170-171.

${ }^{6}$ G. Schmidtchen, Ethik und Protest. Moralbilder und Wertkonflikte junger Menschen, Opladen 1993, s. 104.

7 J. Mariański, Żyć parafiq. Socjologiczne sepekty kierowania wspólnotq parafialnq, Wydawnictwo Księgarni Archidiecezjalnej, Wrocław 1984, ss. 7-9.

8 S. Nowakowski, Zmiany w makrostrukturze społecznej i ich wpływ na lokalne miasta i wsi, „Kultura i Społeczeństwo” 1975, nr 1, s. 95.

${ }^{9}$ H. Steinkamp, Gemeindestruktur und Gemeindeprozess. Versuch einer Typologie, w: Gemeindepraxis. Analasene und Aufgaben, ed. N. Greinacher, Meinz 1979.

${ }^{10}$ S. Knobloch, Praktische Theologie. Ein Lehrbuch fur Studium und Pastoral, Freiburg m Breisgau 1996, ss. 300-305; H. Steinkamp, Gemeindestruktur und Gemeindeprozess..., ss. 79-89. 
W literaturze socjologicznej występują różne określenia przynależności parafialnej katolików, o czym decydują odmienne kryteria definiowania jej przez badaczy. W miarę zobiektywizowaną definicję opisową tej przynależności sformułował Janusz Mariański: „przynależność parafialna to względnie stałe, pozytywne lub negatywne ustosunkowanie się (intelektualne, emocjonalne i behawioralne) jednostki wobec parafii”"11. Z kolei Władysław Piwowarski wskazywał: „,w praktyce można spotkać wiele różnych typów przynależności parafialnej - formalną, rzeczywistą, idealną. Przynależność formalna oznacza nominalny związek jednostki religijnej z parafią, na której terytorium ją ochrzczono. Przynależność rzeczywista oznacza jakiś stopień udziału jednostki w życiu parafii, aczkolwiek udział ten jest zmienny i zróżnicowany, relatywnie zaangażowany w realizację celów wspólnoty parafialnej. Przynależność idealna oznacza postulaty Kościoła instytucjonalnego dotyczące uczestniczenia jednostki w życiu wspólnoty parafialnej ${ }^{12}$.

Jednostka identyfikująca się z parafią uświadamia sobie, że parafia jest grupą, do której i ona sama należy i pozostaje jej członkiem. Zdaniem Janusza Mariańskiego:

[...] identyfikacja z parafią może mieć wymiar subiektywny i obiektywny, albo charakter dystrybutywny i kolektywny. W wymiarze dystrybutywnym jednostka utożsamia się z parafią jako grupą religijną - z jej interesami, dążeniami i celami, solidaryzuje się z innymi parafianami. W wymiarze kolektywnym, z kolei, jednostka identyfikuje się z normami, wartościami, wzorami zachowań akceptowanymi przez grupę, czyli wpierw utożsamia się ona z grupą jako całością, a dopiero później z różnymi jej członkami i strukturami ${ }^{13}$.

\section{Parafia rzymskokatolicka w wyobrażeniach i ocenach badanej młodzieży}

Wiedza dotycząca parafii - jej istoty, zadań, ról i funkcji - należy do czynników mających bezpośredni wpływ na świadomość parafialną katolików, na identyfikację ich ze strukturami parafialnymi, na włączanie się ich w codzienne życie wspólnoty parafialnej, na uczestniczenie w organizacjach religijnych i kulturalnych, które funkcjonują w parafii. Znajomość samej istoty parafii oraz różnych mechanizmów i procesów ułatwiających lub uniemożliwiających skuteczne jej działanie w danej miejscowości bez wątpienia uwrażliwia parafian na jej znaczenie w ich osobistym i publicznym życiu religijnym, rodzinnym i społecznym, pogłębia ich

${ }^{11}$ J. Mariański, Zróżnicowanie pokoleniowe religijności wiejskiej, „Studia Płockie” 1981, nr 9, s. 308.

${ }^{12}$ W. Piwowarski, Religijność miejska w warunkach uprzemysłowienia na przykładzie Puław, „Studia Warmińskie” 1973, t. 10, ss. 36-37.

13 J. Mariański, Przynależność do Kościoła jako problem badawczy, „Chrześcijanin w Świecie” 1972, nr 20, ss. 36-37. 
świadomość parafialną, umożliwia nawiązywanie i utrwalanie styczności i więzi z parafią pochodzenia.

Jan Krucina uważa, że:

[...] funkcje spełniane przez parafię, są takie same, jakie spełnia Kościół, a są one religijne i świeckie. Funkcje religijne, czyli podstawowe, to: a) funkcja głoszenia słowa Bożego - nauczanie i przepowiadanie stanowi początek budzenia wspólnoty chrześcijańskiej; b) funkcja liturgiczno-kultowa, czyli sprawowanie Eucharystii, udzielanie sakramentów i inne praktyki religijne; c) funkcja służenia, posługiwania w miłości oraz świadectwo życia chrześcijańskiego. Funkcje świeckie, z kolei, są liczne i różne, a można je nazwać jako społeczno-kulturowe, czyli ekstensywne lub uzupełniające, mające na celu pomoc wiernym w parafii w ich troskach i potrzebach życiowych ${ }^{14}$.

W socjologii religii parafia jest postrzegana wielorako: jako kategoria społeczna, zbiorowość osób wierzących w Boga, grupa społeczna, grupa celowa, wspólnota wiernych, społeczność religijna ${ }^{15}$. Józef Majka ujmuje parafię integralnie, w wielu aspektach: teologicznym (to wiara, łączność z Kościołem, z Chrystusem, podstawowy cel religijny); kanonicznym (to terytorium, ludzie, kościół, kapłan); socjologicznym (ludność, ośrodki skupienia, czynności społeczne, więzi społeczne) ${ }^{16}$. Definiując parafię, Majka wyraźnie preferuje jej model normatywny, pisząc:

[...] element normatywny przy określaniu cech istotnych parafii, musiałby siłą rzeczy, być postawiony na pierwszym miejscu. Określiłbym parafię nie jako hic et nunc istniejącą rzeczywistość, lecz jako pewien model normatywny, któremu by ta rzeczywistość w mniejszym lub większym stopniu odpowiadała ${ }^{17}$.

\section{a) Istota, funkcje i zadania parafii}

W świetle powyższych wyjaśnień należy zapytać, jak badana młodzież polska postrzegała i wyjaśniała istotę, funkcje i zadania parafii w przyjętym okresie na pograniczu wieku XX i XXI. Czy interpretacja istoty i funkcji parafii była zgodna z założeniami doktrynalnymi i oczekiwaniami Kościoła? Wyniki dostępnych badań socjologicznych ułatwią odpowiedź na te pytania.

Ewa Wysocka, analizując wypowiedzi studentów Uniwersytetu Śląskiego, stwierdziła, że:

[...] w definicjach postulatywnych dominuje pogląd, iż parafia powinna być głównie wspólnotą (89,3\%), niewielki odsetek przypisuje jej jedynie wymiar instytucjonalny

${ }^{14}$ J. Krucina, Gdzie Kościół jest rzeczywistościq społecznq̨?, Wydawnictwo Księgarni Archidiecezjalnej, Wrocław 1993, ss. 11-14.

${ }^{15}$ E. Firlit, Parafia rzymskokatolicka $w$ Polsce $w$ okresie transformacji systemowej..., ss. $32-51$.

16 J. Majka, Socjologia parafii. Zarys problematyki, Towarzystwo Naukowe Katolickiego Uniwersytetu Lubelskiego, Lublin 1971, ss. 23-26.

17 Ibidem, s. 25. 
(7,1\%), zaś incydentalnie postuluje się, iż parafia powinna mieć zarówno instytucjonalny, jak i wspólnotowy charakter (3,6\%); znacząca większość respondentów ocenia, iż parafia jest głównie jednostką organizacji kościelnej (69,0\%), zaś funkcjonowanie jej jako wspólnoty postrzega zaledwie trzecia część tych, którzy taki jej wymiar sami postulowali $(29,8 \%)^{18}$.

Uczniowie szkół średnich w Kaliszu w 2008 roku i studenci Wyższej Szkoły Komunikacji i Zarządzania w Poznaniu w 2011 roku w największym odsetku ujmowali parafię jako „wspólnotę wiernych” (20,0\%), w tym liczniej studenci (23,7\%) niż uczniowie (16,4\%) oraz liczniej kobiety (20,8\%) niż mężczyźni (18,7\%), albo jako „wierni i kapłani” - 13,8\%, w tym częściej studenci (15,7\%) niż uczniowie (12,0\%) oraz częściej mężczyźni (15,6\%) niż kobiety (12,6\%). Łącznie wspólnotowy aspekt parafii dostrzegało 33,8\% badanych, w tym 28,4\% uczniów i 39,4\% studentów oraz 33,4\% kobiet i 35,3\% mężczyzn. Religijny aspekt parafii łącznie dostrzegało 33,1\% badanych, w tym 32,8\% uczniów i 33,8\% studentów oraz 32,5\% kobiet i 33,9\% mężczyzn. Dla 7,3\% badanych parafia oznacza swoiście pojętą „rodzinę katolicką” lub „dom rodzinny”, w której/którym czują się dobrze i bezpiecznie oraz potrzebni innym ludziom, a z tego powodu nie chcą opuszczać „swojej” parafii i przenieść się do innej. Ponadto, 16,8\% badanych osób miało trudności z określeniem istoty parafii albo pominęli pytanie jej dotyczące, w tym 19,5\% uczniów i 13,8\% studentów oraz 18,8\% kobiet i 16,8\% mężczyzn. Określenie istoty parafii łączy się w pewnym stopniu z umiejętnością wskazania przez respondenta jej podstawowych zadań. Dominująca większość tych zadań ma profil religijno-kultyczny, a rzadziej mają one profil świecki. Zdaniem 44,4\% badanych respondentów do głównych zadań parafii należy troska o szeroko pojęte życie religijne parafian, w tym 17,2\% badanych preferowało posługi sakramentalne, ale już mniejszy odsetek wskazał troskę o wiarę religijną wiernych (13,8\%) i o codzienną ich religijność (13,4\%). Pogląd ten podzielało 40,1\% uczniów i 48,8\% studentów oraz 43,2\% kobiet i 46,1\% mężczyzn ${ }^{19}$.

Józef Majka wskazuje, że w parafii: „podobnie jak w organizmie biologicznym, dostrzega się w każdym układzie społecznym cztery główne funkcje: 1) funkcje zachowawcze (konwersacji); 2) funkcje integracji; 3) funkcje dostosowania; 4) funkcje rozwoju”20.

Na jakie funkcje parafii zwracała uwagę badana młodzież polska i które z nich preferowała szczególnie?

${ }^{18}$ W. Wysocka, Parafia w percepcji i doświadczeniach młodzieży studenckiej. Postrzegane funkcje w życiu codziennym i w kreowaniu tożsamości religijnej, „Socjologia Religii” 2003, t. 1, ss. 123-124.

19 J. Baniak, Religia katolicka i Kościół rzymskokatolicki w opiniach polskiej młodzieży. Od akceptacji do kontestacji, Nomos, Kraków 2015, ss. 321-324.

20 J. Majka, Socjologia parafii. Zarys problematyki, Towarzystwo Naukowe Katolickiego Uniwersytetu Lubelskiego, Lublin 1971, ss. 215-216. 
Kwestię funkcji parafii uwzględniono w badaniach w Kaliszu i Poznaniu, pytając uczniów i studentów, jakie funkcje są przypisane, ich zdaniem, parafii, bez podawania im funkcji przykładowych. Cztery funkcje parafii o profilu religijno-kościelnym wskazało łącznie 81,9\% badanych, umieszczając je w następującej kolejności według kryterium znaczenia:

a) funkcja kultyczna - 59,3\% (w tym: 55,7\% uczniowie i 63,1\% studenci oraz 60,2\% kobiety i 58,0\% mężczyźni);

b) funkcja urzędowa 49,55 (w tym: 47,4\% i 51,9\% oraz 51,6\% i 46,8\%);

c) funkcja ideologiczna (wiary) - 44,7\% (w tym: 44,3\% i 45,1\% oraz 51,6\% i 46,8\%);

d) funkcja kościelna - 44,2\% (w tym: 44,8\% i 43,7\% oraz 44,9\% i 43,3\%).

Średnia wskazań tych funkcji wynosi 50,0\% (w tym: 48,2\% i 51,8\% oraz 51,0\% i 49,0\%). Z kolei 18,1\% badanych nie wskazało tych funkcji.

Natomiast 78,0\% respondentów wskazało także pięć funkcji parafii o świeckim profilu, nadając im różny stopień znaczenia i wartości. Funkcje te są następujące:

a) charytatywna - którą wskazało 64,5\% badanych osób, w tym 59,1\% uczniów i 69,5\% studentów oraz 66,5\% kobiet i 61,8\% mężczyzn;

b) integracyjna - którą wskazało 49,0\% badanych, w tym 45,2\% uczniów i 50,9\% studentów oraz 42,7\% kobiet i 55,1\% mężczyzn;

c) społeczna - którą wskazało 45,9\% respondentów, w tym 43,2\% uczniów i 48,8\% studentów oraz 46,9\% kobiet i 44,7\% mężczyzn;

d) ekonomiczno-gospodarcza - którą wskazało 42,2\% badanych osób, w tym liczniej uczniowie - 43,6\% niż studenci - 40,6\% oraz liczniej mężczyźni - 44,4\% niż kobiety - 40,7\%;

e) polityczna - którą wskazał najmniejszy odsetek badanych osób - 25,6\%, w tym 24,6\% uczniów i 26,8\% studentów oraz 21,4\% kobiet i 31,3\% mężczyzn.

Średnia wskazań tych funkcji parafii wynosi 45,2\% (w tym 43,2\% i 47,4\% oraz 43,7\% i 47,3\%).

Funkcje religijne i kościelne parafii liczniej wskazywali jako zasadnicze respondenci głęboko wierzący - 82,6\% i tradycyjnie wierzący - 67,3\%, ale już rzadziej uczynili to respondenci obojętni religijnie - 48,7\% i tylko śladowo respondenci niewierzący - 7,4\%. Z kolei świeckie funkcje parafii najbardziej zainteresowały respondentów niewierzących - 79,3\% i obojętnych religijnie - 46,6\%. Natomiast już znacznie mniejsze odsetki głęboko wierzących $(32,4 \%)$ i tradycyjnie wierzących (47,5\%) doceniły znaczenie tych funkcji w życiu parafii i jej mieszkańców ${ }^{21}$.

Gimnazjaliści z Kalisza i z tutejszego środowiska wiejskiego w 2006 roku odnieśli się również do kwestii istoty, funkcji i zadań parafii, dokonując ich oceny i wyjaśnienia. Badania pozwalają na ukazanie ich interpretacji tego zagadnienia jako: a) bezbłędna - 41,8\% (w tym: uczniowie w Kaliszu - 37,8\% i na wsi - 48,5\%;

${ }^{21}$ J. Baniak, Religia katolicka i Kościół rzymskokatolicki w opiniach polskiej młodzieży..., ss. 324-326. 
b) częściowo poprawna - 17,2\% (w tym odpowiednio: 15,7\% i 18,1\%); c) błędna - 34,2\% (w tym: 27,9\% i 38,0\%); d) brak danych - 6,8\% (w tym: 6,1\% i 7,9\%). Z kolei wskazanie i zrozumienie głównych zadań parafii było: a) bezbłędne - 47,5\% (w tym w Kaliszu - 42,2\% i na wsi - 56,1\%; b) częściowo poprawne - 15,3\% (w tym: 16,8\% i 12,8\%); c) błędne - 30,8\% (w tym: w Kaliszu - 35,0\% i na wsi 24,1\%; brak danych $-6,4 \%$ (w tym: 6,0\% i 7,0\%) ${ }^{22}$.

\section{b) Zainteresowanie sprawami i potrzebami własnej parafii}

Jakie było praktyczne nastawienie badanej młodzieży polskiej w przyjętym okresie do spraw i problemów „własnej” parafii, czyli do parafii pochodzenia, w której aktualnie lub w przeszłości przebywała i spełniała osobiste potrzeby religijne i świeckie? Czy badana młodzież znała podstawowe cechy parafii i księży w niej pracujących? Czy interesowała się sprawami, potrzebami i problemami własnej parafii? Odpowiedź na te pytania dadzą wyniki badań na ten temat.

Elżbieta Firlit zaznacza, że:

[...] sprawy parafialne mają charakter lokalny i konkretny wymiar. Z tego powodu wymagają one od parafian osobistego włączania się w ich tok i rozwiązywanie, a niekiedy też osobistego zaangażowania emocjonalnego. Prawdopodobnie ten powód osłabia zainteresowanie wielu parafian sprawami nurtującymi na co dzień parafię i księży, więc traktują je jako mało ważne lub należące tylko do księży ${ }^{23}$.

Uczniowie szkół średnich i studenci Wydziału Pedagogiczno-Artystycznego UAM w Kaliszu w 2001 roku zainteresowanie sprawami własnych parafii deklarowali w następujący sposób: 33,8\% badanych stwierdziło, że interesują się na bieżąco sprawami (losem) własnej parafii, w tym nieco liczniej uczniowie $(37,1 \%)$ niż studenci (30,6\%). Natomiast 51,3\% respondentów otwarcie stwierdziło, że zupełnie nie interesują ich sprawy i problemy parafii, w których mieszkają lub z których pochodzą, że są im one obojętne, różnie uzasadniając własną postawę, chociaż dwa powody wskazywali najczęściej - osobiste zobojętnienie na zagadnienia religijne i kościelne $(75,4 \%)$ i niechęć do obowiązkowej katechezy w szkole (72,3\%). Niektórzy wskazywali też na brak zainteresowania parafią i jej potrzebami i problemami w swoich rodzinach, zwłaszcza przez własnych rodziców, których negatywny przykład wpłynął na ich podobne podejście do losu parafii $(38,6 \%)$. Brak zainteresowania sprawami własnej parafii ujawnili liczniej studenci (53,1\%) niż uczniowie szkół średnich (49,5\%). Osoby zainteresowane własną

${ }^{22}$ J. Baniak, Między buntem i sprzeciwem a potrzebq akceptacji i zrozumienia. Kryzys tożsamości osobowej a świadomość religijna i moralna młodzieży gimnazjalnej. Studium socjologiczne, Kraków 2008, Wydawnictwo Homini, ss. 284-286.

${ }^{23}$ E. Firlit, Poczucie i przejawy więzi parafialnej w Polsce w latach dziewięćdziesiątych, w: Religijność Polaków: 1991-1998, red. W. Zdaniewicz, Instytut Statystyki Kościoła Katolickiego, Warszawa 2001, ss. 116-117. 
parafią rozmawiały i dyskutowały w swoim środowisku o jej problemach, chociaż z różną częstotliwością: a) bardzo często - 15,7\% (w tym uczniowie - 19,8\% i studenci - 11,5\%), b) często - 11,4\% (w tym, odpowiednio - 11,3\% i 11,6\%), c) rzadko - 13,2\% (w tym: 13,4\% i 13,1\%); łącznie rozmowy i dyskusje o własnej parafii i jej problemach deklarowało 40,3\% badanych osób, w tym 44,5\% uczniów szkół średnich i 36,2\% studentów. W deklaracjach respondentów dotyczących zainteresowania własną parafią i rozmów na jej temat można zauważyć pewną ciągłość - jeśli 51,3\% spośród nich twierdziło, że zupełnie nie interesują się losem własnej parafii, to wskaźnik tego braku zainteresowania wzrasta do 59,7\% wśród tych, którzy nie rozmawiają w swoim środowisku na jej temat ${ }^{24}$.

Zainteresowanie losem własnej parafii przejawia się również w orientacji przynależności parafialnej, w znajomości jej tytułu i imienia patrona, w pamiętaniu daty odpustu parafialnego wiernych. Poprawną lub z pewnymi brakami orientację przynależności parafialnej miało łącznie tylko 45,4\% badanych respondentów, w tym: całkowicie zgodną z rzeczywistością - 33,8\% i częściowo zgodną - 11,6\%. Taką sytuację widzimy u 46,5\% uczniów (w tym co do stopnia zgodności: 35,9\% i $10,6 \%$ ) i u 44,4\% studentów (w tym: 31,7\% i 12,7\%). Natomiast brak rozeznania w tej kwestii wystąpiło u 49,2\% respondentów, w tym u 48,8\% uczniów i u 49,6\% studentów. Znajomość tytułu i imienia patrona parafii potwierdzało 38,5\% uczniów (w tym w pełni - 25,3\% i częściowo - 13,2\%) oraz 37,7\% studentów (w tym: 22,9\% i 14,8\%). Z kolei nie znało tych cech parafii aż 56,6\% badanych, w tym 56,8\% uczniów i 45,3\% studentów. Datę odpustu parafialnego potrafiło wskazać tylko 36,6\% badanych respondentów, w tym nieco większy był wśród nich odsetek uczniów (21,8\%) niż odsetek studentów (20,2\%), zaś błędną datę odpustu wskazało 15,8\% badanych, w tym więcej uczniów (17,9\%) niż studentów (13,6\%). Brak rozeznania w tej kwestii wystąpił u 47,6\% badanych, w tym u 60,3\% uczniów i u 66,2\% studentów ${ }^{25}$.

Jakie było nastawienie tych respondentów do księży pracujących w parafii - czy znali ich nazwisko i imię oraz funkcję spełnianą w parafii? Liczbę księży pracujących w parafii poprawnie wskazało zaledwie 39,7\% badanych, w tym liczniej wśród nich uczniowie (41,1\%) niż studenci (38,3\%), zaś 51,3\% badanych nie znało tej liczby, w tym większy odsetek studentów (53,5\%) niż odsetek uczniów (49,1\%). Z kolei nazwisko i imię proboszcza parafii poprawnie wymieniło tylko 43,0\% respondentów, w tym 44,0\% uczniów i 42,1\% studentów, a trudności z tym miało 48,0\% badanych, w tym większy był odsetek studentów (49,7\%) niż odsetek uczniów (46,2\%). Życiem osobistym księży parafialnych w pełni interesowało się zaledwie 27,3\% badanych, w tym 30,1\% uczniów i 24,5\% studentów, a częściowe zainteresowanie ukazało 15,2\% badanych, w tym 18,3\% uczniów i 12,3\%

${ }^{24}$ J. Baniak, Identyfikacja dwóch pokoleń miejskich z parafiq jako instytucjq kościelnq i wspólnotq społeczno-religijnq, „Studia Gnesnensia” 2003, t. 17, ss. 360-362.

${ }^{25}$ Ibidem, ss. 363-365. 
studentów. Łącznie (na obu poziomach) zainteresowanie to widzimy u 42,5\% respondentów, w tym u 48,3\% uczniów i u 36,8\% studentów. Z kolei pozostali respondenci - 57,5\%, w tym 51,6\% uczniów i 63,2\% studentów, nie zajęli stanowiska w tej sprawie ${ }^{26}$.

Gimnazjaliści w Kaliszu i na wsi deklarowali poprawną znajomość typu własnej parafii w 2006 roku następująco: diecezjalna - 60,0\% (w tym: na wsi - 62,1\% i w Kaliszu - 58,7\%); zakonna - 13,8\% (w tym: 12,5\% i 14,5\%); misyjna - 7,0\% (w tym: 7,3\% i 6,8\%); nie rozróżniali - 14,2\% (w tym: 13,5\% i 14,7\%). Istotę parafii potrafiło określić bezbłędnie - 41,8\% (w tym: na wsi - 48,5\% i w Kaliszu - 37,8\%); częściowo poprawnie - 17,2\% (w tym: 15,7\% i 18,1\%); błędnie określili - 34,2\% (w tym: 27,9\% i 38,0\%). Główne zadania parafii określiło bezbłędnie - 47,5\% (w tym: 56,1\% i 42,2\%); częściowo poprawnie - 15,3\% (w tym: 12,8\% i 16,8\%); błędnie ujęto - 30,8\% (w tym: 24,1\% i 35,0\%) ${ }^{27}$.

Studenci Wyższej Szkoły Komunikacji i Zarządzania w Poznaniu w 2011 roku w 76,6\% potrafili rozróżnić typ parafii, w tym 58,2\% stwierdziło, że jest parafią diecezjalną, a 18,4\% - parafią zakonną, natomiast 19,2\% nie potrafiło dokonać tego rozróżnienia, a 4,2\% nie udzieliło odpowiedzi. Znacznie gorzej studenci orientowali się w znajomości tytułu kanonicznego i imienia patrona parafii, gdyż aż 58,9\% badanych zabrakło wiedzy na ten temat, a zaledwie 23,0\% potrafiło wskazać poprawnie zarówno tytuł parafii, jak i imię jej patrona/patronów, zaś 14,8\% podało błędnie nazwę i imię patrona/patronów parafii, zaś 3,3\% nie odpowiedziało na pytanie. Podobna sytuacja występuje ze znajomością daty odpustu parafialnego, której nie potrafiło wskazać poprawnie aż 63,8\% badanych, a wśród nich byli i tacy, którzy nie wiedzieli, czym jest sam odpust i dziwili się przy tym, że „takie zjawisko” ma miejsce w ich parafii. Konsekwentnie więc poprawną datę odpustu parafialnego wskazało tylko 19,7\% badanych, w tym częściej zrobili to respondenci pochodzący z parafii wiejskich niż z parafii miejskich oraz mieszkający w Poznaniu; natomiast 16,5\% nie udzieliło odpowiedzi na pytanie. Nazwisko i imię proboszcza parafii znało poprawnie 50,7\% badanych, a nazwisko i imię wikariusza/wikariuszy znało tylko 38,5\%, czyli mniej o 12,2\%. Z kolei 46,0\% badanych nie potrafiło wskazać danych osobowych proboszcza tej parafii, a 58,2\% danych innych księży w niej pracujących. Dane te najliczniej poprawnie wskazali studenci praktykujący systematycznie (87,4\%), ale już rzadziej zrobili to praktykujący nieregularnie $(58,6 \%)$ i praktykujący okazjonalnie (31,5\%), zaś niespełniający praktyk religijnych w 80,7\% nie znali tych danych księży parafialnych, 9,3\% znali, jak sami stwierdzili, dane tych księży „z zasłyszenia, ale nie byli przekonani co do ich autentyczności”, zaś pozostali opuścili pytanie dotyczące tej kwestiii ${ }^{28}$.

${ }^{26}$ Ibidem, ss. 366-367.

27 J. Baniak, Między buntem i sprzeciwem a potrzebq akceptacji i zrozumienia..., ss. 282-285.

28 J. Baniak, Religia katolicka i Kościół rzymskokatolicki w opiniach polskiej młodzieży..., ss. 321-330. 
Zainteresowanie parafią i jej sprawami i potrzebami obejmuje także znajomość wspólnot religijnych i organizacji kościelnych czy ruchów religijnych istniejących w parafii, jak i osobisty udział w ich działalności. Czy badana młodzież znała te wszelkiego typu wspólnoty i organizacje religijno-kościelne i włączała się osobiście w ich aktywność wewnętrzną i zewnętrzną? Wyniki dostępnych badań socjologicznych na ten temat umożliwią odpowiedź na to pytanie.

Janusz Mariański informuje, że w badaniach ogólnopolskich w 1988 roku 9,6\% ankietowanej młodzieży szkolnej informowało, że należy i działa aktywnie we wspólnotach religijnych, 20,0\% - należy i nie działa aktywnie, 57,9\% - nie należy, 12,5\% - nie udzieliło odpowiedzi; w 1998 roku, odpowiednio, 74,3\%, 15,0\%, 5,1\%, 5,6\%; w 2005 roku - 70,4\%, 16,7\%, 9,1\%, 3,8\%; w 2017 roku 69,5\%, 18,7\%, 8,4\%, 3,3\%. Do wspólnot i ruchów religijnych oraz stowarzyszeń kościelnych należało według czterech badań od 29,6\%, poprzez 20,1\%, do 27,1\%. Aktywną działalność w ruchach, wspólnotach i stowarzyszeniach kościelnych w 2017 roku równie często deklarowały kobiety, jak i mężczyźni (8,4\% wobec 9,1\%); nieco częściej młodzież ze szkół ogólnokształcących (9,6\%) niż z techników $(7,0 \%)$ i zasadniczych szkół zawodowych (7,9\%); młodzież mieszkająca na wsi $(11,6 \%)$ częściej niż w miastach różnej wielkości (na przykład w miastach do 50 tys. mieszkańców - 7,8\% i w miastach powyżej 500 tys. mieszkańców - 9,6\%). Do aktywności w stowarzyszeniach oraz we wspólnotach religijnych i kościelnych przyznawała się głównie młodzież określająca się jako głęboko wierząca (28,9\%) lub wierząca (12,3\%) oraz jako praktykująca w każdą niedzielę (27,0\%) lub prawie w każdą niedzielę (12,1\%). Osoby o osłabionych więziach z religią tylko sporadycznie informowały o przynależności do ugrupowań religijnych i kościelnych ${ }^{29}$.

Anna Królikowska zaznacza, że studenci z kilku celowo wybranych wydziałów Uniwersytetu Szczecińskiego w 2002 roku deklarowali swój udział w Duszpasterstwie Akademickim (2,8\%), 1,0\% - w Ruchu Światło-Życie, 0,4\% - w Odnowie w Duchu Świętym, 0,4\% - w grupach ministrantów, 0,1\% - we wspólnocie niepełnosprawnych, 0,4\% - w innych wspólnotach i grupach religijnych; 3,4\% - to byli członkowie wspólnot, 0,3\% - planowali przystąpienie do jakiejś grupy czy wspólnoty religijnej. Łącznie jedynie 5,1\% badanych studentów szczecińskich zadeklarowało przynależność do wspólnot i grup religijnych związanych z Kościołem rzymskokatolickim ${ }^{30}$.

Jarosław Kozak informuje, że wśród badanych studentów w pięciu uczelniach w Lublinie (Uniwersytecie Marii Curie-Skłodowskiej, Katolickim Uniwersytecie

29 J. Mariański, Kondycja religijna i moralna młodzieży szkół średnich w latach 1988-19982005-2017 (raport z ogólnopolskich badań socjologicznych), Wydawnictwo Adam Marszałek, Toruń 2018, s. 166.

${ }^{30}$ A. Królikowska, Zachowywanie - porzucanie - dekonstrukcja. Religia w świadomości młodzieży studenckiej. Studium socjologiczne, Wydawnictwo Uniwersytetu Szczecińskiego, Szczecin 2009, s. 82. 
Lubelskim, Uniwersytecie Medycznym, Uniwersytecie Przyrodniczym, Politechnice Lubelskiej) 90,2\% deklarowało własną przynależność wraz z różnorodną systematyczną aktywnością w organizacjach religijnych i stowarzyszeniach katolickich, które funkcjonowały w ich parafiach. Z kolei 4,7\% należało do niektórych organizacji, ale byli mało aktywni dla ich dobra, a w 4,2\% byli biernymi członkami tych wspólnot i organizacji religijno-kościelnych ${ }^{31}$.

Badania Elżbiety Firlit wykazały, że przynależność młodzieży uczącej się w szkołach średnich i studiującej w wyższych uczelniach w Warszawie w 2003 roku do ruchów i wspólnot religijnych w parafii kształtowała się na niskim poziomie. W całej zbiorowości 66,9\% badanych wyraźnie zadeklarowało, że nie należy do jakichkolwiek wspólnot religijnych działających w ramach parafii rzymskokatolickiej, 10,0\% badanych nie należało do Kościoła katolickiego, 4,5\% - należało do Ruchu Światło-Życie, 2,4\% - do Akcji Katolickiej, 1,0\% - do Neokatechumenatu, 0,7\% - do Rodzin Nazaretańskich, 0,4\% - do Opus Dei, 4,9\% - do innych wspólnot religijnych, 9,1\% - brak odpowiedzi ${ }^{32}$.

Magdalena Gwiazda zaznacza, że młodzież z liceów ogólnokształcących, zawodowych i profilowanych, z techników i zasadniczych szkół zawodowych uczestnicząca w badaniach ogólnopolskich w 2002 roku zaledwie w 3,0\% deklarowała przynależność do ruchów i stowarzyszeń istniejących w Kościele rzymskokatolickim oraz w 4,0\% do innych organizacji działających w powiązaniu z tym Kościołem ${ }^{33}$. Z relacji innych socjologów wynika, że w 2008 roku tylko 8,0\% młodzieży badanej przez CBOS deklarowało przynależność do organizacji, stowarzyszeń i klubów religijnych, w 2013 roku - tylko 4,0\% ${ }^{34}$.

Janusz Mariański pisze, że młodzież z klas przedmaturalnych uczestnicząca w badaniach Katedry Socjologii Religii KUL w latach 2002-2005 w czterech miastach tylko w 5,3\% badanych zadeklarowała przynależność i aktywność własną we wspólnotach religijnych w swojej parafii; 2,0\% - że należała, ale była mało aktywna w ich życiu, zaś 90,9\% ujawniło, że nie należało do żadnych organizacji religijnych w swojej parafii. W sumie 7,3\% ankietowanych przynależało - przynajmniej formalnie - do ruchów, wspólnot religijnych i stowarzyszeń katolickich w parafiach: we Włocławku - 5,6\%, w Łomży - 7,8\%, w Ostrowi Mazowieckiej -

${ }^{31}$ J. Kozak, Dzieci postmoderny? Studium socjologiczne nad religijnościq studentów, Wydawnictwo Diecezjalne i Drukarnia w Sandomierzu, Sandomierz 2014, s. 477.

${ }^{32}$ E. Firlit, Młodzież warszawska i parafia, w: Młodzież Warszawy - pokolenie pontyfikatu Jana Pawła II, red. W. Zdaniewicz, S.H. Zaręba, Wydawnictwo Archidiecezji Warszawskiej, Warszawa 2005, ss. 184-185.

${ }^{33}$ M. Gwiazda, Młodzież o sobie: wartości, obyczajowość, grupy odniesienia, w: Młodzież 2003. Opinie i Dagnozy, nr 2. CBOS, Warszawa 2004, ss. 107-109.

${ }^{34}$ Zob. M. Feliksiak, J. Kalka, M. Lutostański, Młodzież o sobie: wartości, obyczajowość, grupy odniesienia, w: Młodzież 2008. Opinie i Diagnozy, nr 13, CBOS, Warszawa 2009, ss. 115-130; R. Boguszewski, M. Feliksiak, M. Gwiazda, J. Kalka, w: red. M. Grabowska, Młodzież 2013. Opinie i Diagnozy, nr 28, CBOS, Warszawa 2013, s. 128. 
4,9\%, w Radomiu - 11,5\%; dziewczęta częściej (7,6\%) niż chłopcy (7,1\%) deklarowały przynależność i aktywność we wspólnotach religijnych i stowarzyszeniach katolickich ${ }^{35}$.

Marcin Rola wykazał, że maturzyści uczący się w szkołach ponadgimnazjalnych w województwie lubelskim, uczestniczący w badaniach w roku szkolnym 2009/2010, w 84,5\% własnej zbiorowości należeli do ruchów i wspólnot religijnych oraz stowarzyszeń katolickich i w różnym stopniu angażowali się osobiście w ich działalność. Czynną przynależność do tych ugrupowań deklarowało 6,1\% ankietowanych, przynależność bierną - 7,9\%. Wśród uczniów z liceów ogólnokształcących wskaźnik „zrzeszonych” wynosił - 15,1\%, z techników - 12,9\%, z liceów profilowanych - 9,3\%; wśród kobiet - 13,2\% i wśród mężczyzn - 14,1\%; wśród młodzieży mieszkającej na wsi - 11,9\%, w miastach do 100 tysięcy mieszkańców - 14,2\%, w miastach powyżej 100 tys. mieszkańców - 14,9\%36. W ocenie Ewy Miszczak wśród maturzystów z całego województwa lubelskiego w 2010 roku 11,7\% badanych deklarowało własne uczestnictwo w różnych organizacjach i wspólnotach religijnych. Kobiety częściej (12,6\%) niż mężczyźni (10,3\%) należały do tych ugrupowań; maturzyści z liceów ogólnokształcących (13,7\%) częściej niż z liceów profilowanych (12,6\%) i z techników ${ }^{37}$.

Maturzyści ze szkół ponadgimnazjalnych w Poznaniu, badani przez Dariusza Kokocińskiego w 2012 roku, deklarowali aż 89,4\% swojej zbiorowości, że należą do różnych wspólnot religijnych i stowarzyszeń katolickich istniejących w ich parafii, 4,1\% - należy, ale słabo angażowali się w ich działalność; 6,5\% - należeli i byli aktywni w ich środowisku ${ }^{38}$.

Maciej Dębski informuje, że wśród młodzieży szkół ponadgimnazjalnych w Gdańsku na początku XXI wieku 8,0\% badanych deklarowało przynależność do organizacji i wspólnot o charakterze religijnym (Oaza, Odnowa w Duchu Świętym, Neokatechumenat, ministranci) i niewiele więcej wyrażało chęć i pragnienie przynależenia do takiej formacji (14,0\%). Co czwarty uczeń w ostatnich latach uczestniczył w pielgrzymce parafialnej i co dziesiąty ankietowany brał udział w inicjatywach o charakterze religijno-parafialnym (akcje charytatywne, koncerty muzyki religijnej itp. $)^{39}$.

35 J. Mariański, Emigracja z Kościoła. Religijność młodzieży polskiej w warunkach zmian społecznych, Wydawnictwo Katolickiego Uniwersytetu Lubelskiego, Lublin 2008, ss. 194-197.

${ }^{36}$ M. Rola, Wartości moralne w świadomości maturzystów lubelskich. Studium socjologiczne, Drukarnia Standruk, Lublin 2016, s. 134.

37 E. Miszczak, Świętość w religijnej świadomości maturzystów województwa lubelskiego. Studium socjologiczne, Wydawnictwo Uniwersytetu Marii Curie-Skłodowskiej, Lublin 2014, ss. $149-150$.

38 Zob. J. Mariański, Tożsamości religijne w społeczeństwie polskim. Studium socjologiczne, Wydawnictwo Adam Marszałek, Toruń 2017, s. 392.

39 M. Dębski, Wiara „na skróty”. Szkic o religijności polskiej młodzieży, „Więź” 2003, nr 5, s. 58. 
Badania Andrzeja Górnego wykazały, ze wśród młodzieży z województwa śląskiego w 2002 roku 13,5\% badanych określiło siebie jako aktywnych członków różnego rodzaju ruchów i wspólnot religijnych. Najczęściej ankietowani wymieniali Ruch Światło-Życie, a następnie - ministrantów; 6,0\% - to osoby uczestniczące od czasu do czasu w spotkaniach wspólnotowych i 1,5\% - sympatycy wspólnot religijnych. W całej zbiorowości młodzieży śląskiej 74,0\% ankietowanych nie należało do wspólnot religijnych, a 5,0\% - nie udzieliło odpowiedzi na ten temat ${ }^{40}$.

Marek Adamczyk zaznacza, że w Radomiu w 2005 roku 8,0\% badanych uczniów szkół ponadgimnazjalnych deklarowało aktywną przynależność do ruchów i wspólnot religijnych oraz stowarzyszeń katolickich oraz 3,5\% - przynależność bierną. Zdecydowana większość tych uczniów nie należała do ruchów i wspólnot religijnych działających w parafiach $-88,5 \%{ }^{41}$.

Kazimierz Skoczylas zaznacza, że wśród młodzieży szkół ponadgimnazjalnych z trzech powiatów regionu konińskiego w 2009 roku 7,7\% badanej młodzieży deklarowało, że należy i działa aktywnie w parafialnych wspólnotach religijnych, 15,3\% - że należy i jest mało aktywna, 75,8\% - że nie należy i 1,1\% - inne odpowiedzi. W środowiskach wiejskich 72,5\% ankietowanych nie należało go ugrupowań religijno-kościelnych w parafii, w małych miastach - 85,8\%, w średnich miastach $-69,7 \%$ i w wielkich miastach $-63,6 \%{ }^{42}$.

\section{c) Identyfikacja z własną parafią i kościołem parafialnym}

Jednym z kryteriów, które określają znaczenie parafii jako podstawowej wspólnoty kościelnej, jest identyfikacja mieszkańców z parafią, a wskaźniki tej identyfikacji są różne w zależności od typu parafii i od stosunku do niej poszczególnych wiernych.

Na czym polega identyfikacja z parafią? Stella Grotowska twierdzi:

Identyfikacja z parafią w czasach globalizacji spełnia niezwykle istotną funkcję - służy ponownej integracji polegającej na wytwarzaniu tożsamości, która może zyskać potwierdzenie instytucjonalne i tym samym zagwarantować sobie znacznie większą stabilność i trwałość. W perspektywie globalności - lokalności pojawia się pytanie dotyczące strukturalizacji tożsamości: jaka jest rola wymiaru religijnego, określanego przez religijność i instytucję wobec innych identyfikacji, bo przecież różne sfery współczesnej kultury globalnej różnią się pod względem obligatoryjności obowiązują-

${ }^{40}$ A. Górny, Młodzież a parafia. Obraz parafii w świadomości młodzieży w województwie śląskim, w: Parafia jako rzeczywistość wielowymiarowa, red. J. Baniak, Redakcja Wydawnictw Wydziału Teologicznego Uniwersytetu im. Adama Mickiewicza, Poznań 2003, s. 141.

${ }^{41}$ M. Adamczyk, Obszary i zakres zróżnicowania religijności polskiej młodzieży, w: Wartości i postawy młodzieży polskiej, red. D. Walczak-Duraj, t. 1, Wydawnictwo Uniwersytetu Łódzkiego, Łódź 2009, s. 201.

${ }^{42}$ K. Skoczylas, Wartości młodych katolików regionu konińskiego. Studium katechetyczno-pastoralne na przykładzie wybranych szkół ponadpodstawowych regionu konińskiego, Wydawnictwo Uniwersytetu Mikołaja Kopernika, Toruń 2011, s. 286. 
cych w nich reguł: najbardziej represyjne są obszary ekonomii i technologii, najmniej - estetyki, obyczaju, religii, które składają się na jednostkową wolność. [...] Parafia uosabia i materializuje coś, co swojskie i znane, pewne i odwieczne, a zarazem jest związane z religią, która stanowi enklawę ludzkiej wolności, dlatego zaznaczająca się humanizacja czy laicyzacja religii idzie w parze z poczuciem związku z parafią. Ponadto parafia jest rodzajem lokalnej agory, publiczną przestrzenią, w której spotyka się to, co globalne, z tym, co lokalne ${ }^{43}$.

\section{Elżbieta Firlit dodaje w tym kontekście:}

Poziom identyfikacji z parafią jest zróżnicowany w poszczególnych kategoriach społecznych. Z przeprowadzonych badań wynika, że głównym kryterium tych zróżnicowań są takie cechy, jak: globalny stosunek do wiary i praktyk religijnych, wiek, miejsce zamieszkania oraz poziom wykształcenia. I tak: a) wśród osób głęboko wierzących i osób uczestniczących systematycznie w praktykach religijnych mamy najwyższy odsetek tych, którzy w zdecydowanym stopniu czują się związani ze swoją parafią; b) identyfikacja z parafią wyraźnie wzrasta wraz z wiekiem badanych - im ludzie są starsi, tym silniej czują się związani z parafią, zaś wskaźnik zdecydowanej identyfikacji z parafią jest ponad dwukrotnie wyższy wśród osób w wieku siedemdziesięciu i więcej lat niż u osób w wieku 20-29 lat; c) istotnym czynnikiem warunkującym emocjonalny związek z parafią jest miejsce zamieszkania - stosunkowo najczęściej i relatywnie najsilniej występuje on wśród mieszkańców wsi (66,3\%), zaś w dużych miastach jest o 27 punktów procentowych niższy; d) poziom subiektywnego związku z parafią obniża się wraz ze wzrostem wykształcenia ludności - można powiedzieć, że autoidentyfikacja $\mathrm{z}$ parafią jest ciągle odwrotnie proporcjonalna do poziomu wykształcenia ${ }^{44}$.

Jak kształtowała się w tym czasie identyfikacja badanej młodzieży polskiej z parafią macierzystą i z kościołem parafialnym? Badania socjologiczne umożliwiają odpowiedź na to pytanie. Uczniowie szkół średnich w Kaliszu (2008) i studenci Wyższej Szkoły Komunikacji i Zarządzania w Poznaniu (2011) deklarowali identyfikację z własną parafią w następujący sposób: a) całkowicie - 43,5\%, w tym: liczniej uczniowie (50,4\%) niż studenci (36,1\%) oraz liczniej kobiety (44,9\%) niż mężczyźni (41,7\%); b) częściowo - 18,0\%, w tym: liczniej studenci (20,2\%) niż uczniowie (16,0\%) oraz liczniej mężczyźni (18,2\%) niż kobiety $(17,9 \%)$; łączny wskaźnik identyfikacji (pełnej i częściowej) obu grup respondentów z parafią kształtował się na poziomie 61,5\%, w tym wśród uczniów - 66,4\% i wśród studentów - 56,3\% oraz kobiet - 62,8\% i wśród mężczyzn - 59,9\%. Natomiast 33,2\% respondentów, w tym większy odsetek studentów (39,4\%) niż uczniów (27,2\%) oraz większy odsetek mężczyzn (34,5\%) niż kobiet - 32,1\%), stwierdziło, że nie identyfikują się z własną parafią, oni także nie mieli poczucia identyfikacji z Kościołem instytucjonalnym. Z drugiej zaś strony trzeba zaznaczyć, że wśród respondentów

${ }^{43}$ S. Grotowska, Identyfikacja z parafiq w czasach globalizacji, „Socjologia Religii” 2003, t. 1 , s. 308.

${ }^{44}$ E. Firlit, Postawy społeczeństwa polskiego wobec parafii rzymskokatolickiej na przełomie wieków, „Socjologia Religii” 2003, t. 1, s. 171. 
dominują uczniowie i studenci identyfikujący się z własną parafią nad tymi, którzy nie utożsamiali się z nią i jej potrzebami i problemami (61,5\% wobec 33,2\%), w tym w grupie uczniów (66,4\% wobec 27,2\%) i studentów (56,3\% wobec 39,4\%) oraz wśród kobiet (62,8\% wobec 32,1\%) i mężczyzn (59,9\% wobec 34,5\%) ${ }^{45}$.

Identyfikacja z parafią wyraża się także w emocjonalnym nastawieniu tej młodzieży do niej oraz w ocenie jej wartości i ważności w porównaniu z innymi parafiami sąsiednimi. Badania wykazały, że emocjonalne nastawienie respondentów w obu grupach do parafii było znacznie zróżnicowane - od nastawienia pozytywnego przez obojętne do skrajnie negatywnego. Pozytywne nastawienie do parafii deklarowało 31,0\% badanych osób, w tym nieco więcej uczniów (32,7\%) niż studentów (29,1\%) oraz więcej kobiet (32,1\%) niż mężczyzn (29,4\%). Z kolei nastawienie negatywne i krytyczne do własnej parafii przejawiało łącznie 29,0\% badanych, w tym więcej studentów (30,3\%) niż uczniów (27,8\%), a także więcej mężczyzn (31,8\%) niż kobiet (28,5\%). Natomiast dla 22,3\% badanych osób, w tym dla większego odsetka studentów (26,5\%) niż uczniów $(18,4 \%)$ oraz dla większego odsetka kobiet (24,2\%) niż mężczyzn (19,8\%), parafia własna jest kompletnie obojętną rzeczywistością - jako instytucja kościelna i jako wspólnota religijna i lokalna. Jeśli połączymy wskaźniki respondentów negatywnie i obojętnie nastawionych do parafii macierzystej, wtedy uzyskamy łączny wskaźnik 51,3\% badanych, którzy w ten krytyczny sposób świadomie sprzeciwiali się oddziaływaniu parafii na własną religijność i moralność, ponieważ postawy negatywne i krytyczne oraz postawy obojętne taki właśnie sprzeciw i opór symbolizują i powodują. Taki stosunek do parafii pochodzenia deklarowało 46,2\% uczniów i u 56,8\% studentów oraz 51,2\% kobiet i 55,6\% mężczyzn. Pozostały odsetek respondentów (12,1) nie ujawnił własnego nastawienia emocjonalnego do parafii, w tym więcej uczniów $(14,5 \%)$ niż studentów $(9,6 \%)$ oraz więcej mężczyzn $(13,4 \%)$ niż kobiet $(11,2 \%)^{46}$.

Czy badani tu respondenci opuściliby własną parafię i osiedlili się w innej parafii? Jakie przyczyny umożliwiłyby im porzucenie własnej parafii dla innej parafii? Respondenci ocenili własną parafię względem innych parafii w następujący sposób: a) zdecydowanie lepsza - 12,4\% (w tym uczniowie - 14,9\% i studenci - 9,6\% oraz kobiety - 13,4\% i mężczyźni - 11,0\%); b) raczej lepsza - 13,6\% (w tym: 15,4\% i $11,7 \%$ oraz 13,8\% i 13,4\%); łącznie była ona lepsza od innych parafii w ocenie $26,0 \%$ badanych (w tym dla: 30,3\% i 21,3\% oraz dla 27,2\% i 24,4\%; c) taka sama jak każda inna - 19,0\% (w tym: 19,3\% i 18,9\% oraz 16,5\% i 22,5\%); d) raczej gorsza od innych parafii - 17,6\% (w tym: 16,4\% i 18,8\% oraz 18,1\% i 16,8\%); e) zdecydowanie gorsza - 12,9\% (w tym: 11,6\% i 14,3\% oraz 11,8\% i 14,4\%). Większy odsetek respondentów (30,5\%) ocenił zatem gorzej własną parafię niż odsetek oceniających ją lepiej od innych parafii (26,0\%), porównując w tym celu zestaw

45 J. Baniak, Religia katolicka i Kościół rzymskokatolicki w opiniach polskiej młodzieży..., s. 331.

${ }^{46}$ Ibidem, ss. 332-334. 
jej cech pozytywnych i negatywnych z takimi cechami dostrzeżonymi w innych parafiach. Ponadto 18,9\% badanych nie potrafiło dokonać takiej oceny dla własnej parafii w porównaniu jej z innymi parafiami, postrzegając ją jako lepszą lub jako gorszą, a w tym 15,8\% uczniów i 22,3\% studentów oraz 20,9\% kobiet i 16,3\% mężczyzn. Parafię własną uznały za gorszą od innych parafii osoby wyraźnie zniechęcone do niej i liczniej wskazujące jej wady niż zalety. Jednocześnie 46,8\% respondentów nie wyjechałoby do innej parafii, a taką deklarację złożyło 48,2\% uczniów szkół średnich i 45,3\% studentów oraz 49,8\% kobiet i 42,8\% mężczyzn. W tej grupie 28,0\% zdecydowanie wykluczało emigrację z własnej parafii, w tym liczniej uczniowie (33,3\%) niż studenci (22,3\%) oraz liczniej kobiety (32,1\%) niż mężczyźni (22,5\%). Z kolei 18,8\% twierdziło, że „raczej” nie opuściliby swojej parafii (w tym: uczniowie - 23,0\% i studenci - 14,9\% oraz kobiety - 20,3\% i mężczyźni - 17,7\%). Natomiast 38,5\% badanych osób wyemigrowałoby do innych parafii, jeśli zachęciłyby lub zmusiłby ich do takiej decyzji ważne sprawy czy problemy osobiste lub rodzinne, a wśród nich było 33,8\% uczniów i 43,4\% studentów oraz 36,3\% kobiet i 41,5\% mężczyzn; przy czy 19,2\% zdecydowałoby się na wyjazd z własnej parafii bezwarunkowo, a 19,3\% - pod presją ważnych warunków i powodów. Parafii własnej nie opuściliby respondenci systematycznie praktykujący (70,3\%) i praktykujący nieregularnie (50,6\%), ale już rzadziej taką deklarację złożyli praktykujący okazjonalnie (37,5\%). Z kolei respondenci zaniedbujący realizację praktyk religijnych liczniej emigrowaliby do innych parafii (48,8\%), uzasadniając taką możliwość różnymi względami ${ }^{47}$.

\section{d) Osobista więź młodzieży z macierzystą parafią}

Poczucie więzi jednostki z parafią macierzystą jest jednym z podstawowych składników jej religijności i świadomości parafialnej. Elżbieta Firlit zaznacza, że „poczucie to wyraża się dwubiegunowo: w wymiarze subiektywnym, czyli w procesie identyfikacji jednostki z tą parafią i z jej codziennymi problemami i potrzebami, oraz w wymiarze obiektywnym, czyli w podejmowaniu różnych ważnych i znaczących dla parafii działań, jak również w przynależności do różnych struktur parafialnych"48.

Czy młodzież badana miała poczucie więzi z własną parafią, czy też takiej więzi nie odczuwała? Wypowiedzi młodzieży na to pytania zostaną ukazane w dalszej analizie tego zagadnienia.

W badaniach zrealizowanych przez Józefa Baniaka w 2006 roku w gimnazjach Kalisza i w gimnazjach wiejskich w tutejszym rejonie ustalono, że 29,4\% ankietowanych określiło swoje poczucie więzi z parafią jako całkowite, 44,0\% - jako częściowe, 19,3\% - jako brak poczucia więzi z parafią i 7,3\% - nie udzieliło

47 Ibidem, ss. 334-335.

${ }^{48}$ E. Firlit, Poczucie i przejawy więzi parafialnej..., s. 116. 
odpowiedzi. Deklaracje dotyczące więzi z parafią chłopców i dziewcząt oraz gimnazjalistów miejskich i wiejskich były zbliżone do siebie ${ }^{49}$.

Uczniowie ze szkół średnich i studenci wyższych uczelni działających w diecezji koszalińsko-kołobrzeskiej, badani przez Remigiusza Szauera w latach 2014-2015, więź z własną parafią deklarowali w następujący sposób: a) zdecydowanie tak -9,6\% (w tym uczniowie - 10,8\% i studenci - 8,0\% oraz kobiety - 10,2\% i mężczyźni $8,2 \%$ ); b) raczej tak - 23,3\% (w tym, odpowiednio - 25,2\% i 20,7\% oraz 22,9\% i 24,3\%); c) trudno powiedzieć - 17,9\% (w tym: 19,2\% i 15,7\% oraz 17,3\% i 19,1\%); d) raczej nie - 23,5\% (w tym: 22,0\% i 25,7\% oraz 23,4\% i 23,8\%); e) zdecydowanie nie - 25,7\% (w tym: 22,8\% i 29,9\% oraz 26,2\% i 24,6\%). Okazuje się, że aż 49,2\% respondentów nie odczuwało więzi z własną parafią, w tym 44,8\% uczniów i 55,6\% studentów oraz 49,6\% kobiet i 48,4\% mężczyzn. Z kolei więź osobistą z własną parafią odczuwało łącznie 32,9\% respondentów, w tym 36,0\% uczniów i 28,7\% studentów oraz 33,1\% kobiet i 32,5\% mężczyzn. Różnica między wskaźnikiem osób, które nie odczuwały więzi z własną parafią i wskaźnikiem tych osób, które taką więź odczuwały wynosi 16,3 p.p. dla osób bez więzi parafialnej (49,2\% wobec 32,9\%) ${ }^{50}$.

Studenci Wydziału Pedagogiczno-Artystycznego Uniwersytetu im. Adama Mickiewicza z Poznania funkcjonującego w Kaliszu, którzy uczestniczyli w badaniach socjologicznych Józefa Baniaka w 1998 roku, na pytanie o poczucie osobistej więzi z parafią macierzystą udzielili następujących odpowiedzi: a) mam bardzo silne i trwałe poczucie więzi - 8,7\%, b) mam silne i trwałe poczucie więzi -12,3\%, c) mam przeciętne i nietrwałe poczucie więzi - 15,3\%, d) mam bardzo słabe i okazjonalne poczucie więzi - 9,4\%, e) zupełnie nie odczuwam poczucia więzi z parafią - 48,1\%, f) nie potrafię tego ocenić - 6,2\%. Okazuje się, że silne i trwałe poczucie więzi z własną parafią deklarowało zaledwie 21,0\% badanych studentów, zaś poczucie słabe i nietrwałe czy okazjonalne deklarowało łącznie 24,7\%. Łącząc wskaźniki zróżnicowanego poziomu poczucia więzi z parafią, otrzymujemy wskaźnik 45,7\% respondentów przejawiających więź parafialną na „umiarkowanym” poziomie zaangażowania emocjonalnego w tę więź. Wskaźnik ten jest zbliżony do wskaźnika studentów deklarujących brak poczucia więzi z własną parafią (48,1\% wobec 45,7\%). Poczucie więzi z parafią macierzystą liczniej deklarowały studentki (51,6\%) niż studenci (42,3\%), a brak tego poczucia więzi z parafią liczniej ujawnili studenci (56,4\%) niż studentki (39,7\%). Różnica między ich wskaźnikami wynosiła: w odniesieniu do poczucia więzi parafialnej - 9,3 p.p. dla kobiet, a w odniesieniu do braku poczucia więzi - 16,7 p.p. dla mężczyzn ${ }^{51}$.

${ }^{49}$ J. Baniak, Między buntem i sprzeciwem a potrzebq akceptacji i zrozumienia. Kryzys tożsamości osobowej a świadomość religijna i moralna młodzieży gimnazjalnej. Studium socjologiczne, Homini, Kraków 2008, s. 287.

${ }^{50}$ R. Szauer, Między potrzebq doznań a trwałościq̨ postaw. Religijność i moralność uczniów szkół średnich i studentów uczelni wyższych w diecezji koszalińsko-kołobrzeskiej. Studium socjologiczne, Warszawskie Wydawnictwo Socjologiczne, Warszawa 2019, ss. 298-299.

${ }^{51}$ J. Baniak, Identyfikacja dwóch pokoleń miejskich z parafiq..., ss. 368-369. 
Poczucie więzi emocjonalnej z własną parafią deklarowali również uczniowie szkół średnich w Kaliszu w 2008 roku w następującym porządku: łącznie - 66,2\% badanych, w tym 34,2\% mówiło o więzi trwałej, a u 32,0\% więź ta była niestabilna i o częściowym jej poczuciu. Najliczniej trwałą więź z macierzystą parafią deklarowali głęboko wierzący (89,2\%) i wierzący (69,5\%), a także systematycznie spełniający praktyki religijne (76,5\%) i niesystematycznie (57,8\%); natomiast obojętni religijnie mówili tylko o więzi „przejściowej” czy „okazjonalnej” (27,2\%) i tak samo praktykujący w wyjątkowych sytuacjach i okolicznościach (18,6\%). Poczucie więzi z własną parafią deklarowało 69,6\% kobiet, w tym 32,2\% miało poczucie całkowite, a 37,4\% poczucie częściowe, także miało to poczucie więzi parafialnej 58,1\% mężczyzn, w tym 29,3\% poczucie pełne i 29,8\% poczucie częściowe. Natomiast $27,2 \%$ twierdziło, że nie mają żadnych styczności i powiązań z własną parafią. Brak tej więzi deklarowali często uczniowie obojętni religijnie (66,3\%) i niewierzący $(75,8 \%)$ oraz zaniedbujący $(54,9 \%)$ i niespełniający praktyk religijnych (70,4\%), a także nieuczestniczący w katechezie szkolnej (47,7\%). Brak poczucia więzi z parafią zgłosiło 25,8\% uczennic i 35,8\% uczniów badanych szkół średnich ${ }^{52}$.

Na wzmocnienie więzi parafialnych mogą oddziaływać bezpośrednio różne czynniki, w tym stałe kontakty wiernych z osobami duchownymi. Maturzyści poznańscy w 2012 roku zapytani przez Dariusza Kokocińskiego, jaki wpływ na twoją wiedzę i opinie w sprawach religii mają w parafii księża, udzielili następujących odpowiedzi: bardzo duży wpływ $-15,1 \%$, raczej duży wpływ $-37,7 \%$, raczej mały wpływ $-21,0 \%$, bardzo mały wpływ $-10,0 \%$, nie mają wpływu $-13,4 \%$, trudno powiedzieć - 2,8\%; a wpływ katechezy (odpowiednio) - 14,9\%, 35,4\%, 20,8\%, $10,4 \%, 15,9 \%, 2,6 \%{ }^{53}$.

Studenci Wyższej Szkoły Komunikacji i Zarządzania w Poznaniu w 2011 roku poczucie więzi osobistej z własną parafią deklarowali następująco: a) całkowite 26,7\%, b) częściowe - 36,4\%; poczucie łącznie deklarowało - 63,1\% badanych; c) brak poczucia więzi z parafią - 32,4\%. Poczucie więzi z parafią deklarowało: 62,8\% studentek (w tym 40,7\% całkowite) i 57,2\% studentów (w tym 32,6\% całkowite); 84,3\% głęboko wierzących (64,2\% całkowite); 69,1\% wierzących (45,3\% całkowite); 47,4\% obojętnych religijnie (27,2\% całkowite); 76,9\% praktykujących systematycznie (54,6\% całkowite); 58,4\% praktykujących nieregularnie (37,6\% całkowite); 38,8\% praktykujących okazjonalnie (19,5\% całkowite) ${ }^{54}$.

Gimnazjaliści w Kaliszu i w środowisku wiejskim w 2006 roku osobiste poczucie więzi z macierzystą parafią deklarowali w następujący sposób: a) całkowite

52 J. Baniak, Religia katolicka i Kościół rzymskokatolicki w opiniach polskiej młodzieży..., ss. 337-339.

${ }^{53}$ Zob. J. Mariański, Tożsamości religijne w społeczeństwie polskim..., s. 411.

54 J. Baniak, Religia katolicka i Kościół rzymskokatolicki w opiniach polskiej młodzieży..., s. 339. 
i trwałe - 29,4\% (w tym w Kaliszu - 33,8\% i na wsi - 22,5\%; dziewczęta - 30,0\% i chłopcy - 28,2\%); b) częściowe i nietrwałe - 44,0\% (w tym, odpowiednio: 39,\% i 51,0\% oraz 45,0\% i 42,0\%); łącznie poczucie więzi parafialnej deklarowało 73,4\% (w tym: 73,3\% i 70,5\% oraz 75,0\% i 68,7\%); c) brak poczucia więzi z parafią 19,3\% (w tym: $20,0 \%$ i $18,1 \%$ oraz $18,4 \%$ i $21,0 \%)^{55}$.

\section{e) Zaangażowanie młodzieży w życie społeczne własnej parafii}

Wysoki poziom świadomości parafialnej młodzieży polskiej może zachęcać ją lub przełożyć się na jej osobiste zaangażowanie w różne sfery życia parafialnego podejmowane dla jej dobra ogólnego, zarówno jako instytucji kościelnej, jak i jako wspólnoty religijnej i społecznej. Elżbieta Firlit zaznacza, że „działania na rzecz parafii dzielą się na następujące grupy: 1) świadczenia pieniężno-materialne na rzecz parafii; 2) wykonywanie różnych prac przy obiektach parafialnych; 3) uczestnictwo w parafialnej działalności charytatywnej”56.

Janusz Mariański dodaje:

[...] katolicy polscy, w miarę swoich chęci i możliwości, włączają się w te formy aktywności parafialnej - jedni we wszystkie trzy ich typy, z kolei inni wyłącznie w niektóre z nich, a pozostali angażują się zaledwie „śladowo” w sprawy i zadania własnej parafii. Jednak wśród parafian są też tacy, którym potrzeby i problemy ich parafii są zupełnie obojętne, nic ich one nie obchodzą, w wyniku czego nie aktywizują się w żaden sposób dla jej dobra materialnego i duchowego ${ }^{57}$.

Przejawem więzi z parafią jest ofiarność pieniężna parafian na rzecz swojej parafii, która jest związana z obowiązkiem wynikającym z przykazania kościelnego nakazującego dbałość o materialne potrzeby Kościoła i lokalnej wspólnoty. Elżbieta Firlit dodaje w tej kwestii:

[...] składanie ofiary pieniężnej na tacę podczas niedzielnej mszy świętej jest czymś więcej niż tylko behawioralnym wskaźnikiem więzi z parafią. Składki na tacę są dla polskich katolików stałym, usankcjonowanym przez tradycję, elementem społecznych zachowań praktykującego parafianina. „Chodzenie za składką” w czasie mszy świętej i składanie przez wiernych pieniędzy na obnoszoną tacę jest wkomponowane w liturgię mszy świętej, a więc ma związek z zachowaniami religijnymi, ale równocześnie jest to głęboko zinternalizowany wzór zachowań społecznych, jest to powszechnie uznawany i realizowany obyczaj społeczny ${ }^{58}$.

55 J. Baniak, Między buntem i sprzeciwem a potrzebq akceptacji i zrozumienia..., ss. 286-287. 114-115.

${ }^{56}$ E. Firlit, Parafia rzymskokatolicka w Polsce $w$ okresie transformacji systemowej..., ss.

57 J. Mariański, Kościół katolicki w Polsce w przestrzeni życia publicznego. Studium socjologiczne, Wydawnictwo Adam Marszałek, Toruń 2013, ss. 234-239.

${ }^{58}$ E. Firlit, Parafia rzymskokatolicka w Polsce w okresie transformacji systemowej..., s. 119. 
Jakie działania na rzecz własnej parafii podejmowała młodzież szkolna i akademicka w Polsce w przyjętym okresie? Wyniki dostępnych badan socjologicznych pozwolą na sformułowanie wypowiedzi na to pytanie. Gimnazjaliści w Kaliszu i w tutejszym rejonie wiejskim w 2006 roku własne zaangażowanie na rzecz własnej parafii określili w następujący sposób: 14,2\% - jako systematyczne, 29,6\% - jako nieregularne, $17,8 \%$ - jako okazjonalne, 30,0\% - jako niepodejmujący takich działań i 8,7\% - nie udzieliło odpowiedzi na to pytanie ${ }^{59}$.

Studenci Wydziału Pedagogiczno-Artystycznego Uniwersytetu im. Adama Mickiewicza w Poznaniu funkcjonującego w Kaliszu w 1998 roku deklarowali następujące formy aktywności na rzecz swoich parafii: a) świadczenia pieniężne składane na tacę podczas mszy niedzielnych i świątecznych - 54,4\%, b) pomoc pod różną postacią w parafii i przy kościele parafialnym - 25,3\%, c) udział w zarządzaniu strukturami parafialnymi (np. w radzie parafialnej) - 7,6\%, d) działalność charytatywna dla ludzi biednych, samotnych, starych i zmarginalizowanych społecznie - 24,5\%, e) aktywność w młodzieżowych organizacjach religijnych i kościelnych działających w parafii - 16,6\%, f) udział w organizacji pielgrzymek do miejsc kultu religijnego, w tym na Jasną Górę do Częstochowy - 31,7\%, g) brak zaangażowania dla dobra parafii - 63,5\%; łącznie we wszystkich formach aktywności proparafialnej uczestniczyło 32,3\% badanych studentów kaliskich, w tym częściej kobiety - 38,6\% niż mężczyźni - 31,8\% ${ }^{60}$.

Studenci Wyższej Szkoły Komunikacji i Zarządzania w Poznaniu w 2011 roku deklarowali następujące formy aktywności dla swoich parafii: a) składki pieniężne na tacę w czasie mszy niedzielnych i świątecznych $-57,7 \%$, b) pomoc w różnej postaci na plebanii i kancelarii parafialnej - 10,3\%, c) pomoc w pracach przy kościele parafialnym zleconych przez księży - 17,8\%, d) pomoc organizacyjna w parafii i liturgiczna w kościele parafialnym - 12,0\%, e) prace fizyczne w gospodarstwie parafialnym - 27,5\%, f) działalność charytatywna i wolontariat z nią związany - 34,7\%, g) aktywność w ruchach religijnych i stowarzyszeniach kościelnych istniejących w parafii - 22,1\%, h) działalność w ośrodku duszpasterstwa akademickiego - 13,7\%; łącznie w tych formach aktywności parafialnej uczestniczyło 29,6\% badanych studentów, natomiast $65,9 \%$ w ogóle nie angażowało się w jakąkolwiek aktywność i pomoc dla własnych parafii ${ }^{61}$.

Uczniowie szkół średnich w Kaliszu w 2008 roku deklarowali następujące formy własnej pomocy: a) dając pieniądze na tacę w czasie mszy niedzielnych i świątecznych - 66,2\%, b) pomagając w różny sposób na plebanii - 15,8\%, c) pomagając w różnych pracach przy kościele parafialnym - 24,1\%, d) uczestnicząc w organizowaniu różnych imprez w parafii - 19,7\%, e) wykonując prace fizyczne

59 J. Baniak, Między buntem i sprzeciwem a potrzebq akceptacji i zrozumienia..., s. 287.

${ }^{60}$ J. Baniak, Identyfikacja dwóch pokoleń miejskich z parafiq..., ss. 380-381.

61 J. Baniak, Religia katolicka i Kościół rzymskokatolicki w opiniach polskiej młodzieży..., s. 350 . 
w różnych obiektach parafialnych - 38,2\%, f) wolontariat charytatywny - 28,8\%, g) wolontariat obejmujący różne potrzeby i problemy w parafii - 26,3\%, h) aktywność w grupach młodzieżowych religijnych i świeckich w parafii - 34,0\%, i) brak osobistej aktywności proparafialnej - 47,8\%; łącznie we wszystkich formach zaangażowania dla dobra własnej parafii uczestniczyło 33,4\% badanych uczniów szkół średnich, w tym częściej dziewczęta - 39,6\% niż chłopcy - 34,7\% ${ }^{62}$.

\section{Podsumowanie}

Podsumowując analizy przeprowadzone w tym artykule, można stwierdzić, że parafia jest rzeczywistością wielowymiarową i tak postrzegała ją badana młodzież gimnazjalna, licealna i akademicka w Polsce w uwzględnionym przedziale czasu. Młodzież badana dobrze wie, że w parafii „dzieje się” całość życia religijnego, kościelnego i społecznego wszystkich jej członków i pozostałych jej mieszkańców - w jej strukturach i poprzez jej funkcje religijne i świeckie są wypełniane religijną treścią kolejne etapy biografii jednostek ludzkich - od urodzenia do momentu naturalnej śmierci. Z tym faktem zgadzała się większość badanej młodzieży w każdej grupie. To podejście pozwalało młodzieży oceniać parafię rzeczowo i krytycznie, a także stawiać opór niektórym jej funkcjom i zadaniom świeckim oraz pewnym elementom doktryny kościelnej, popularyzowanym w nauczaniu i działaniu praktycznym.

Dla wielu respondentów w każdej grupie parafia nie jest już miejscem i środowiskiem bliskim, przyjaznym i oswojonym, dlatego nie czują się związani z nią emocjonalnie i praktycznie, nie identyfikują się z jej podstawowymi celami, potrzebami i zadaniami, kwestionują jej rolę religijną we własnej religijności, nie odczuwają potrzeby osobistego zaangażowania się w realizację jej zadań i pomnażania je dóbr materialnych i duchowych. W zasadzie ci respondenci znajdują się już poza zasięgiem wpływów parafii, są wyobcowani i zobojętniali wobec jej spraw, potrzeb i problemów, nie interesują się jej losem aktualnym i perspektywicznym.

Jednocześnie trzeba zaznaczyć, że dokładne porównanie wskaźników empirycznych nastawienia pozytywnego i nastawienia negatywnego badanej młodzieży szkolnej i akademickiej do parafii z lat wchodzących w dwie końcowe dekady XX wieku oraz w obie dekady XXI wieku wskazuje, że: a) odsetki respondentów pozytywnie nastawionych do parafii były większe w zakresie ich postaw i działań na jej rzecz w obu końcowych dekadach XX wieku niż odsetki respondentów w obu dekadach XXI wieku; b) zmniejszanie się odsetków respondentów, którzy nie utożsamiali się z parafią, nie mieli z nią styczności i osobistej więzi, nie angażowali się w prace i działania dla jej dobra, wystąpiło już w pewnym zakresie w końcowej dekadzie minionego wieku, a nasiliło się znaczniej w obecnym wieku,

62 Ibidem, s. 349. 
zwłaszcza w drugiej jego dekadzie w każdej wskazanej wyżej sferze; c) gimnazjaliści i licealiści częściej niż studenci identyfikowali się z parafią, częściej deklarowali poczucie więzi osobistej z nią i z kościołem i duchowieństwem parafialnym, częściej też włączali się w czyny służące dobru własnej parafii jako wspólnocie religijnej i świeckiej.

Wśród czynników oddziałujących na nastawienie badanej młodzieży polskiej do parafii jako instytucji kościelnej i wspólnoty wiernych największy wpływ miała jej postawa religijna i postawa niereligijna. Pozytywne nastawienie do parafii i chęć służenia jej pomocą i wsparciem najliczniej i najczęściej przejawiali uczniowie i studenci głęboko wierzący i regularnie spełniający obowiązkowe praktyki religijne. Nastawienie to jest już słabsze wśród respondentów wierzących tradycyjnie i praktykujących nieregularnie. Z kolei krytyczne i negatywne nastawienie do parafii i brak chęci służenia jej pomocą najliczniej były widoczne u uczniów i studentów deklarujących postawę niereligijną czy ateistyczną oraz całkiem zaniedbujących praktyki religijne.

\section{Literatura}

Adamczyk M., Obszary i zakres zróżnicowania religijności polskiej młodzieży, w: Wartości i postawy młodzieży polskiej, red. D. Walczak-Duraj, t. 1, Wydawnictwo Uniwersytetu Łódzkiego, Łódź 2009.

Baniak J., Identyfikacja dwóch pokoleń miejskich z parafiq jako instytucjq kościelnq i wspólnotq społeczno-religijnq, „Studia Gnesnensia” 2003, t. XVII.

Baniak J., Między buntem i sprzeciwem a potrzebq akceptacji i zrozumienia. Kryzys tożsamości osobowej a świadomość religijna i moralna młodzieży gimnazjalnej. Studium socjologiczne, Wydawnictwo Homini, Kraków 2008.

Baniak J., Religia katolicka i Kościół rzymskokatolicki w opiniach polskiej młodzieży. Od akceptacji do kontestacji, Nomos, Kraków 2015.

Boguszewski R., Feliksiak M., Gwiazda M., Kalka J., Młodzież o sobie: wartości, obyczajowość, grupy odniesienia, w: Młodzież 2013. Opinie i diagnozy, nr 28, red. M. Grabowska, J. Kalka, CBOS, Warszawa 2014.

Boguszewski R., Od zinstytucjonalizowanej do zindywidualizowanej religijności Polaków w procesie przemian, w: Globalny i lokalny wymiar religii. Polska w kontekście europejskim, red. I. Borowik, A. Górny, W. Świątkiewicz, Nomos, Kraków 2016.

Bonicelli G., La parrocchia Italaiano la vent'anni dal Concilio Vaticano II, w: Oltre l'indifferenza. La parrocchia a vent'anni dal Conzilio, Edizione Dehoniane, Napoli 1985.

Dębski M., Wiara „na skróty”. Szkic o religijności polskiej młodzieży, „Więź” 2003, nr 5.

Feliksiak M., Kalka J., Lutostański M., Młodzież o sobie: wartości, obyczajowość, grupy odniesienia, w: Młodzież 2008. Opinie i Diagnozy, nr 13, CBOS, Warszawa 2009.

Firlit E., Młodzież warszawska i parafia, w: Młodzież Warszawy - pokolenie pontyfikatu Jana Pawła II, red. W. Zdaniewicz, S.H. Zaręba, Wydawnictwo Archidiecezji Warszawskiej, Warszawa 2005. 
Firlit E., Parafia rzymskokatolicka w Polsce w okresie transformacji systemowej. Studium socjologiczne, Elipsa, Warszawa 1998.

Firlit E., Poczucie i przejawy więzi parafialnej w Polsce w latach dziewięćdziesiątych, w: Religijność Polaków: 1991-1998, red. W. Zdaniewicz, ISKK, Warszawa 2001.

Firlit E., Postawy społeczeństwa polskiego wobec parafii rzymskokatolickiej na przełomie wieków, „Socjologia Religii” 2003, t. 1.

Goddijn W., Sichtbare Kirche. Okumene und Pastoral, Herder, Wien 1967.

Górny A., Młodzież a parafia. Obraz parafii w świadomości młodzieży w województwie śląskim, w: Parafia jako rzeczywistość wielowymiarowa, red. J. Baniak, Redakcja Wydawnictw Wydziału Teologicznego UAM, Poznań 2003.

Grotowska S., Identyfikacja z parafiq w czasach globalizacji, „Socjologia Religii” 2003, t. 1.

Gwiazda M., Młodzież o sobie: wartości, obyczajowość, grupy odniesienia, w: Młodzież 2003. Opinie i diagnozy, nr 2, CBOS, Warszawa 2004.

Kamiński R., Parafia jako forma urzeczywistniania się Kościoła, w: Dei Virtus. Kardynałowi Bolesławowi Kominkowi w hołdzie, red. J. Krucina, Wydawnictwo Księgarni Archidiecezjalnej, Wrocław 1974.

Knobloch S., Praktische Theologie. Ein Lehrbuch fur Studium und Pastoral, Freiburg im Breisgau 1996.

Kozak J., Dzieci postmoderny? Studium socjologiczne nad religijnościq studentów, Wydawnictwo Diecezjalne i Drukarnia w Sandomierzu, Sandomierz 2014.

Królikowska A., Zachowywanie - porzucanie - dekonstrukcja. Religia w świadomości młodzieży studenckiej. Studium socjologiczne, Wydawnictwo Uniwersytetu Szczecińskiego, Szczecin 2009.

Krucina J., Gdzie Kościół jest rzeczywistościq̨?, Wydawnictwo Księgarni Archidiecezjalnej, Wrocław 1993.

Majka J., Socjologia parafii. Zarys problematyki, Towarzystwo Naukowe KUL, Lublin 1971.

Mariański J., Kościół katolicki w Polsce w przestrzeni życia publicznego. Studium socjologiczne, Wydawnictwo Adam Marszałek, Toruń 2013.

Mariański J., Emigracja z Kościoła. Religijność młodzieży polskiej w warunkach zmian społecznych, Wydawnictwo KUL, Lublin 2008.

Mariański J., Kondycja religijna i moralna młodzieży szkół średnich w latach 1988-19982005-2017 (raport z ogólnopolskich badań socjologicznych), Wydawnictwo Adam Marszałek, Toruń 2018.

Mariański J., Przynależność do Kościoła jako problem badawczy, „Chrześcijanin w Świecie” 1972, nr 20.

Mariański J., Religijność maturzystów puławskich w procesie przemian, „Zeszyty Naukowe KUL” 2017, nr 2(60).

Mariański J., Tożsamości religijne w społeczeństwie polskim. Studium socjologiczne, Wydawnictwo Adam Marszałek, Toruń 2017.

Mariański J., Zróżnicowanie pokoleniowe religijności wiejskiej, „Studia Płockie” 1981, nr 9.

Mariański J., Żyć parafiq̨. Socjologiczne aspekty kierowania wspólnotq parafialnq, Wydawnictwo Księgarni Archidiecezjalnej, Wrocław 1984.

Metz R., Goddijn W., La paroisse en France al époque moderne et contemporaine, „Revue d'Histoire de l'Eglise de France” 1975, nr 166.

Miszczak E., Świętość w religijnej świadomości maturzystów województwa lubelskiego. Studium socjologiczne, Wydawnictwo UMCS, Lublin 2014. 
Nowakowski S., Zmiany w makrostrukturze społecznej i ich wpływ na lokalne miast i wsi, „Kultura i Społeczeństwo” 1975, nr 1.

Piwowarski W., Problemy duszpasterskie w strefie urbanizacji, „Przegląd Powszechny” 1982, nr 3.

Piwowarski W., Religijność miejska w warunkach uprzemysłowienia na przykładzie Puław, „Studia Warmińskie” 1973, t. 10.

Rola M., Wartości moralne w świadomości maturzystów lubelskich. Studium socjologiczne, Drukarnia Sandruk, Lublin 2016.

Schmidtchen G., Ethik Und Protest. Moralbilder und Wertkonflikte junger Menschen, Opladen 1993.

Skoczylas K., Wartości młodych katolików regionu konińskiego. Studium katechetyczno-pastoralne na przykładzie wybranych szkół ponadpodstawowych regionu konińskiego, Wydawnictwo Naukowe Uniwersytetu Mikołaja Kopernika, Toruń 2011.

Steinkamp H., Gemeindestruktur und Gemeindeprozess. Versuch einer Typologie, w: Gemeindepraxis. Analasene und Aufgaben, ed. N. Greinacher, Meinz 1979.

Szauer R., Między potrzebq doznań a trwałościq postaw. Religijność i moralność uczniów szkół średnich i studentów uczelni wyższych w diecezji koszalińsko-kołobrzeskiej. Studium socjologiczne, Warszawskie Wydawnictwo Socjologiczne, Warszawa 2019.

Świątkiewicz W., Młodzież a religia, w: Leksykon pedagogiki religii, red. C. Rogowski, Verbinum, Warszawa 2007.

Wysocka E., Parafia w percepcji i doświadczeniach młodzieży studenckiej, „Socjologia Religii” 2003, t. 1. 